\title{
Replacement of native by non-native animal communities assisted by human introduction and management on Isla Victoria, Nahuel Huapi National Park
}

Valeria L Martin-Albarracin, Martin A Nuñez, Guillermo C Amico

One of the possible consequences of biological invasions is the decrease of native species abundances or their replacement by non-native species. In Andean Patagonia, southern Argentina and Chile, many non-native animals have been introduced and are currently spreading. On Isla Victoria, Nahuel Huapi National Park, many non-native vertebrates were introduced ca. 1937. Records indicate that several native vertebrates were present before these species were introduced. We hypothesize that seven decades after the introduction of non-native species and without appropriate management to maintain native diversity, non-native vertebrates have displaced native species -given the known invasiveness and impacts of some of the introduced species-. We conducted direct censuses in linear transects $500 \mathrm{~m}$ long $(n=10)$ in parallel with camera-trapping (1253 camera-days) surveys in two regions of the island with different levels of disturbance: high $(n=4)$ and low $(n=6)$ to study the community of terrestrial mammals and birds and the relative abundances of native and non-native species. Results show that currently non-native species are dominant across all environments; $60.4 \%$ of census records and $99.7 \%$ of camera trapping records are of non-native animals. We detected no native large mammals; the assemblage of large vertebrates consisted of five non-native mammals and one non-native bird. Native species detected were one small mammal and one small bird. Species with a highest trapping rate were red and fallow deer, wild boar, silver pheasant (the four species nonnative) and chucao (a native bird). These results suggest that native species are being displaced by non-natives and are currently in very low numbers. 
1 Replacement of native by non-native animal communities assisted by human introduction

2 and management on Isla Victoria, Nahuel Huapi National Park

3

4 Valeria L. Martin-Albarracin ${ }^{1 *}$, Martin A. Nuñez ${ }^{1}$, Guillermo C. Amico ${ }^{1}$

5

$6 \quad{ }^{1}$ Laboratorio Ecotono, INIBIOMA, CONICET-Universidad Nacional del Comahue, Bariloche,

7 Río Negro, Argentina

8 * Corresponding author; Address: Quintral 1250, 8400, Bariloche, Río Negro, Argentina; Phone

9 number: 00540261 155737448; E-mail address: valemartinalba@gmail.com.ar

10

11

12

13

14

15

16

17

18

19

20

21

22

23

24

25

26

27

28

29

30

31

32

33

34 


\section{Introduction}

Although the invasion by non-native species is currently recognized as one of the main threats to global biodiversity, historically this was not always the case. Throughout human history there have been many intentional introductions with the aim of naturalizing species considered valuable. For example, in Hawaii 679 species were purposely introduced and released between 1890 and 1985 for the biological control of pest species; $243(35.8 \%)$ of them have become established (Funasaki et al. 1988). Similarly, in the United States $85 \%$ of 235 woody species naturalized were introduced primarily for the landscape trade and $14 \%$ for agriculture or production forestry (Reichard 1994). Interestingly, many populations of non-native species known to have impacts are currently not managed or are protected because they constitute economic resources or have cultural importance (Lambertucci \& Speziale 2011; Nuñez \& Simberloff 2005). Moreover, intentional attempts to introduce new species are still common (Hulme et al. 2008). Together, these factors contribute to the colonization and success of 50 invasive species.

One main objective of protected areas is the protection of native biodiversity (Naughton-Treves et al. 2005). However, without appropriate management, establishment of a protected area is not enough to protect native biodiversity (Leverington et al. 2010). Biological invasions in particular are an important threat to protected areas because they can have large impacts on native species

56 (Simberloff et al. 2013). Moreover, an invasive species can be unintentionally introduced or

57 reach a protected area by spreading from other sites (e.g. Fasola et al. 2011). If not controlled,

58 these species can increase in abundance and become a serious problem. 
60 We can expect three different scenarios as the result of the introduction of non-native species

61 (MacDougall et al. 2009). One is a scenario where non-native species do not survive or are

62 reduced to very low numbers, possibly owing to biotic resistance from native species (Zenni \&

63 Nuñez 2013). Another is where native and non-native species coexist, which could be explained,

64 for example, by the existence of empty niches that are filled by non-native species (Azzurro et al.

65 2014). The third scenario is where natives are gradually driven to extinction and replaced by

66 non-natives (Blackburn et al. 2004; Woinarski et al. 2015). In this last scenario biological

67 invasions become a very important threat to native biodiversity.

68

69 In Andean Patagonia, southern Argentina and Chile, biological invasions are a serious problem, even in National Parks (Sanguinetti et al. 2014), where the highest invasion indices have been recorded in relation to other protected areas in Argentina (Merino et al. 2009). For example,

72 studies on the diet of an assemblage of native carnivores found that their diet comprises almost exclusively non-native animals, indicating that these have replaced native species as a food source for native carnivores (Novaro et al. 2000). Similarly, the diet of the condor (Vultur gryphus), a scavenging bird of South America, was historically dominated by guanacos (Lama guanicoe) and lesser rheas (Rhea pennata), the dominant herbivores of the region, but now has

77 shifted and comprises mainly non-native species (Lambertucci et al. 2009). Research in forests and shrublands of Patagonia shows that terrestrial communities are dominated by non-native

79 mammals, including several invasive species such as Cervus elaphus (red deer), Sus scrofa (wild boar) and Lepus europaeus (European hare, Gantchoff et al. 2014). Moreover, the association of

81 some of these species to human-disturbed environments such as roads or pine plantations can 
82 increase their rate of spread (Gantchoff et al. 2014; Lantschner et al. 2012). Many of these data

83 suggest that the actual problem is not a single species invasion, but a multi-species invasion.

85 Isla Victoria, located in the centre of Nahuel Huapi National Park, has a history of invasions, 86 with many species of plants and animals actively introduced for several decades (Simberloff et 87 al. 2002). In 1937 a zoological station was established on the island with the aim of exhibiting 88 native and exotic fauna to tourists and promoting hunting (Daciuk 1978a). Non-native species

89 included some of the most invasive vertebrates in the world; such as red deer (C. elaphus,),

90 fallow deer (Dama dama), and several pheasant species. The zoological station closed in 1959

91 and animals were released. Since then, non-native species had not received any significant

92 management, though various proposals have been advanced occasionally (Daciuk 1978a).

93 Recently, records of native mammals on Isla Victoria have diminished drastically, and those of 94 non-native mammals have become common.

96 The aim of this study is to assess the community composition of terrestrial mammals and birds in

97 Isla Victoria several decades after the introduction of non-native species. Specifically, we recorded all species detected, and, for the more common species, we estimated the population

99 density and their association with different disturbance levels. We hypothesize that (1) without 100 appropriate management, non-native species have become dominant; and (2) that given the 101 adaptation of some non-native species to human altered habitats, highly disturbed areas will 102 harbor greater abundances and diversity of non-native animals than less disturbed areas.

\section{Methods}


106 Study site

107

108 The study was conducted in Isla Victoria, located in the core of Nahuel Huapi National Park, in

109 the northern Patagonian Andes, Argentina (405 $57 \mathrm{~S}, 71^{\circ} 33 \mathrm{~W}$, APN research permit $\mathrm{N}^{\circ} 1146$ ).

110 This island is located in the center of Nahuel Huapi Lake, a glacial lake with $557 \mathrm{~km}^{2}$ surface

111 that is located at an altitude of 770 masl. The island has a surface of $31 \mathrm{~km}^{2}$ and a maximum

112 altitude of 1050 masl. The climate is cold and temperate with a pronounced seasonality. The

113 island is dominated by forests of native Nothofagus dombeyi (Coihue) and Austrocedrus

114 chilensis (Ciprés) (Simberloff et al. 2003). Since the beginning of the $20^{\text {th }}$ century, this island has

115 been the focus of many animal and plant introductions, most of them conducted for economic

116 purposes.

118 Old World deer C. elaphus (red deer), D. dama (fallow deer), and C. axis (axis deer) were

119 introduced to this region between 1917 and 1922 as game animals (Simberloff et al. 2003). In

1201937 a zoological station was constructed to raise animals for exhibition to tourists and to

121 promote hunting (Daciuk 1978a). The first two deer species successfully established and are

122 common in the island (Relva et al. 2009), while the last one became extinct. Several species of

123 phasianids were also introduced, including peacocks (Pavo cristatus), golden pheasants

124 (Chrysolophus pictus), silver pheasants (Lophura nycthemera), dark pheasants (Phasianus sp.),

125 and ring-necked pheasants (Phasianus colchicus) (Daciuk 1978a).

126 
127 Sus scrofa (wild boar) was seen for the first time in the island in 1999. This species was

128 introduced to Patagonia in the early 1900 s and probably reached the island swimming from the

129 nearby Huemul Peninsula (Simberloff et al. 2003; see Fig. 1), although is also possible that it

130 was illegally and covertly introduced. They are now reproducing regularly and are widespread

131 along the island (Barrios-Garcia et al. 2014). Other non-native species more recently established

132 on the island is Neovison vison (American mink), introduced to Patagonia in 1940s and currently

133 spreading (Fasola et al. 2011). Domestic cats, F. domesticus, were brought to the island by the

134 first settlers (date unknoun). Several cats escaped from domestication and are now living and

135 reproducing in a wild state. Non-native rodents of the genera Mus and Rattus can be found in the

136 most intensively used ports of the island - Anchorena, Piedras Blancas, and Radal (Fig. 1).

137 Several of these non-native species have been introduced in other regions of the world with

138 reported ecosystem impacts (Barrios-Garcia \& Ballari 2012; Fasola et al. 2011; Relva et al.

139 2010; Woinarski et al. 2015). The list of species introduced and naturalized on isla Victoria is 140 presented on Table 1.

142 The original assemblage of native terrestrial vertebrates on Isla Victoria was relatively simple,

143 consisting on a subset of few species respective to the total fauna of Nahuel Huapi National Park

144 (Table 2) (Grigera et al. 1994). It was composed of several lizards of the genus Liolaemus, a

145 snake, two terrestrial birds and some small mammals (Contreras 1973; Daciuk 1978b). Two

146 native cervids were observed on Isla Victoria in early 1900s, Pudu pudu (pudú) and

147 Hippocamelus bisulcus (Austral huemul, Daciuk 1978b; Koutché 1942). References indicate that

148 H. bisulcus was common on the island at the beginning of the $20^{\text {th }}$ century. Remains of this

149 species have been found in excavations at Puerto Tranquilo, in the north coast of the island (E. 
150 Ramilo, personal communication). On the contrary, there is not enough evidence to say that $P$.

151 pudu inhabited the island. Instead, individuals observed probably reached the island from

152 populations surrounding Nahuel Huapi Lake (Eduardo Ramilo, Personal Communication). Pudu

$153 p u d u$ was introduced to the island at the zoological station, and some recent sightings indicate

154 that it is still present, although it appears to be very scarce; however, there are no reported

155 sightings of $H$. bisulcus from the last decades

156 (http://www.sib.gov.ar/area/APN*NH*Nahuel\%20Huapi\#eves).

158 Sampling Design

160 To study the composition of the community of terrestrial vertebrates in Isla Victoria we installed 161 one camera trap in each of eight 500m-transects from winter 2011 to autumn 2012 (Fig. 1).

162 Transects were associated with two different levels of human disturbance: high (4 transects) and

163 low (4 transects). High disturbance occurred in regions where tourist activities are developed,

164 with tens to hundreds of people walking along paths daily. These regions include plantations of

165 non-native trees and shrublands with high abundances of non-native plants. Regions with low

166 disturbance were occasionally visited by people who inhabit the island. These regions are

167 dominated by forests of $N$. dombeyi and A. chilensis and by mixed shrublands dominated by

168 native plants. We used eight heat and motion-triggered infrared cameras; six were model

169 Bushnell Trophy Cam 119736C (Bushnell, Overland Park, Kansas), and the other 2 were Stealth

170 Cam Unit IR (Stealth Cam, Grand Prairie, Texas). Cameras were located haphazardly along

171 transects, installed at a height of $30-50 \mathrm{~cm}$ and programmed to take videos 40 seconds long with a

172 1-min delay between exposures. Locations of the cameras were chosen based on visibility, but 
173 we did not seek animal trails (Rowcliffe et al. 2008). After 2-5 weeks, videos were downloaded

174 and cameras were relocated along transects at new sites. The overall effort was of 1253 camera

175 days (minimum camera days per transect $=86$; maximum $=289$; average $=156.6$ ).

176

177 In addition to camera-trapping, direct census of animals was conducted through a distance-

178 sampling approach. The sampling was conducted using the same eight transects as with the

179 camera traps, plus two extra transects $(\mathrm{N}=10)$ located in low-disturbance areas (Fig. 1). We

180 walked the transects 3 to 5 times at an average speed of $2 \mathrm{~km}$ per hour recording all the terrestrial

181 mammals and birds detected (sighted or heard), and their perpendicular distances to the transect.

182 For further analyses, perpendicular distances were truncated at $0,5,10,15,20,30,50,100$ and

$183150 \mathrm{~m}$.

184

185 Data analysis

186

187 Study of habitat use

188

189 To compare habitat use at high vs. low disturbance sites, for each of the most frequently captured

190 animals (deer, pheasant, and boar) we calculated the relative abundance index (RAI). This index

191 was calculated as the number of independent captures obtained through camera-trapping (C)

192 divided by trapping effort (TE) and multiplied by 100 camera-days. We considered captures of

193 the same species as independent only when there was a difference of at least one hour between

194 captures of studied species.

$195 R A I=\frac{C}{T E * 100 \text { camera }- \text { days }}$ 
197 As the effective trapping area differs widely among species with different body size (Rowcliffe 198 et al. 2011), RAI was not used to make comparisons between species.

Estimation of population density

201

202 Population density was estimated from distance sampling data (Buckland et al. 2007). The half203 normal (HN), hazard-rate (HAZ) and exponential (EXP) key functions for detection probability 204 were fitted to truncated data of distance. For species with over 30 sightings (L. nycthemera and 205 S. rubecula), we used type of environment (plantation, forest and shrubland) as a covariate of 206 detection probability and level of disturbance (high or low) as a covariate of density (Marques et 207 al. 2007). For the other species we used no covariates. The Akaike Information Criterion (AIC) 208 together with diagnostic plots were used to choose between models (Appendix 1).

210 For each species we conducted a regression of log observed cluster size vs. estimated detection

211 probability to test for size bias (i.e. tendency to observe larger clusters at longer distances). In all

212 cases, the regression slope was not significantly different from zero $(\mathrm{P}>0.46)$. We thus used

213 mean observed cluster size as an estimate of expected cluster size to calculate animal densities.

214 Cluster size data were obtained from camera trap videos.

\section{Results}

218 Habitat use 
220 We obtained a total of 710 independent captures of 8 mammal and terrestrial bird species

221 through camera trapping. The species detected included one native small mammal $(O$.

222 longicaudatus), five non-native mammals (C. elaphus, D. dama, S. scrofa, F. domesticus and N.

223 vison), one native bird (S. rubecula) and one non-native bird (L. nycthemera). The great majority

224 of captures (99.7\%) were of non-native animals (Fig. 2). The species detected most frequently

225 were non-native deer (55.4\% of captures including both species), L. nycthemera (31.2\%), and $S$.

226 scrofa (11.3\%). We did not capture other native species reported in the island by Daciuk (1978b).

227 Deer captures were identified at species level when possible (83\% of captures; $65 \%$

228 corresponded to C. elaphus and $35 \%$ to D. dama).

229

230 At highly disturbed sites we detected seven species, while at low disturbance sites we observed

231 five. The only species detected in low disturbance sites but not in highly disturbed regions was

232 N. vison. Three species were detected only in highly disturbed regions: F. domesticus, $S$.

233 rubecula and O. longicaudatus (but the last two had only one capture each). Lophura

234 nycthemera was relatively more abundant in highly disturbed areas than in low disturbance areas

235 (Pearson's chi-squared test, $\mathrm{p}=0.001$; Fig. 3), while relative abundance indices of deer and $S$.

236 scrofa did not vary among sites.

237

238 Population density

239

240 We detected five terrestrial animals through direct censuses: L. nycthemera, C. elaphus, D.

241 dama, S. scrofa and S. rubecula. For L. nycthemera, the best model fit was achieved by the 
242 exponential key function, with type of environment as a covariate for detection and level of

243 disturbance as a covariate for density. Lophura nycthemera density was nearly twice as high

$244(1.79 \pm 0.52 \mathrm{ind} / \mathrm{ha})$ in highly disturbed areas than in low disturbance areas $(0.99 \pm 0.42 \mathrm{ind} / \mathrm{ha})$.

245 For S. rubecula, best fit model used the hazard rate key function and level of disturbance as a

246 covariate for density. S. rubecula density was more than twice as high in low disturbance areas

$247(0.73 \pm 0.19 \mathrm{ind} / \mathrm{ha})$ than in highly disturbed areas $(0.32 \pm 0.12 \mathrm{ind} / \mathrm{ha})$. For deer, the best fit model

248 used the hazard rate key function, and estimated density was $0.12 \pm 0.05$ ind/hectare. For $S$.

249 scrofa, the best fit model used the exponential key function and estimated density at $0.27 \pm 0.16$

$250 \mathrm{ind} /$ hectare.

252 Discussion

253

254 Our results show that at least six non-native species have successfully established on Isla

255 Victoria and become dominant. By contrast, we found very few native species detections. Non-

256 native deer (C. elaphus and D. dama), S. scrofa, and L. nycthemera were among the most

257 abundant species on Isla Victoria, and only L. nycthemera showed greater abundance in highly

258 disturbed areas than in low disturbance areas. While it is difficult to assess whether non-native

259 species are displacing native species (because there is no quantitative information of native

260 populations before non-native species introductions), it is likely that the successful establishment

261 of the non-natives could have contributed to their decline.

262

263 The current assemblage of non-native animals on the island results from a combination of

264 intentional and unintentional introductions of species and range expansions of invasive species 
265 from the continent. Old World deer and pheasants, for example, were intentionally introduced.

266 Non-native rodents present on the island may have been introduced unintentionally through

267 transport in the hold of ships. Some species that are believed to have reached the island by 268 expansion of their invading ranges are S. scrofa and Neovison vison.

270 Several factors can influence the likelihood that an introduced species will become established.

271 On Isla Victoria many factors such as species traits, propagule pressure, and climatic matching

272 have helped non-native species invasions. Cervus elaphus, D. dama, S. scrofa, P. colchicus, and

273 N. vison are known to have specific traits that make them good invaders in many regions (Table

274 3). In addition, the introduction of species bred in the zoological station was not a unique event,

275 but animals were released continuously for several years, increasing propagule pressure and

276 therefore increasing the likelihood of successful establishment (Lockwood et al. 2005).

277 Moreover, the area possibly offered an empty niche for some species (Azzurro et al. 2014). The

278 absence of big predators, for example, may have aided naturalization by non-native vertebrates.

279 Similarly, land birds in Patagonian forests are small in relation to non-native pheasants, which

280 may have different requirements. All these factors made Isla Victoria an ideal site for species

281 naturalization. As result of these multiple invasions, together with inadequate management, the

282 current assemblage of terrestrial mammals and birds on the island is highly dominated by non-

283 native species, in both composition and abundance.

285 Disturbance has long been cited as a factor that helps non-native species colonization and

286 invasion (Hobbs \& Huenneke 1992). Thus, the association of non-native animals with highly-

287 disturbed areas such as conifer plantations could be facilitating the invasion of natural areas by 
288 non-native herbivores (Lantschner et al. 2012). Our results showed that the only non-native

289 animal that consistently associated with highly disturbed areas was L. nycthemera. Cervus

290 elaphus, D. dama and S. scrofa, instead, made a similar use of low and high disturbance areas.

291 Previous studies in the area showed that $C$. elaphus and S. scrofa prefer pine plantations instead

292 of native vegetation at the landscape scale (Lantschner et al. 2012) and revealed a positive

293 association of $S$. scrofa with roads (Gantchoff \& Belant 2015). These results and our study thus

294 suggest that deer, S. scrofa, and L. nycthemera are highly capable of using human-disturbed

295 habitats. While deer and S. scrofa can also reach high abundances in native environments, and

296 for instance have large impacts on native species inhabiting them, L. nycthemera may remain

297 strongly associated with human-disturbed environments and scarce in native environments. $S$.

298 rubecula, the only native land bird detected, was strongly associated with low disturbed

299 environments. This could simply be due to the preference for native habitats (Lantschner \&

300 Rusch 2007), but it is also possible that the pheasant is displacing it from plantations.

301 Pteroptochos tarnii coexists with $S$. rubecula in all areas surrounding Isla Victoria (Amico et al.

302 2008), but it was not detected in this study. We hypothesize that both human disturbance and the

303 presence of non-native species may be affecting P. tarnii abundance (Lantschner \& Rusch 2007;

304 Skewes et al. 2007).

305

306 One fact that can have a big impact on native biodiversity is the naturalization of non-native

307 terrestrial carnivores, N. vison and F. domesticus, because the original assemblage of vertebrates

308 on isla Victoria had no terrestrial carnivores (see Table 2). Thus, these species can have an

309 important role as predators of birds and small mammals. A species that can be seriously affected

310 by the naturalization of $N$. vison is imperial shag, Phalacrocorax atriceps, a species that nests at 
311 steep rocky cliffs of the island and that is considered of special value by the National Park

312 Service (Pozzi \& Ramilo 2011). Neovison vison and F. domesticus can also be involved in the

313 apparent local extinction of $P$. tarnii and can threat populations of other native ground-nesting

314 birds such as S. rubecula.

315

316 We must take into account that the low number of native species detections may be partially

317 explained by the low body mass of some species (Dromiciops gliroides, Oligoryzomys

318 longicaudatus, S. rubecula and P. tarnii). Trap cameras have a bigger effective trapping area for

319 species of higher body mass; for example in Barro Colorado Island studies found that effective

320 detection distance is about $1.3 \mathrm{~m}$ for species of low boy mass (mouse unknown species, body

321 mass $=0.1 \mathrm{~kg}$ ) and about $3.5 \mathrm{~m}$ for species of higher body mass (Collared peccary Tayassu tajacu,

322 body mass $=25.2 \mathrm{~kg}$ ) (Rowcliffe et al. 2011). However, camera-trapping has been used

323 succesfully for the study of small birds and mammals (Kays et al. 2011). In our study, through

324 direct census $S$. rubecula was much more frequently detected -usually by its song - than big

325 mammals, and estimated densities exceeded those of deer and S. scrofa. P. tarnii, however, also

326 has an identifiable song but was never detected in direct censuses. Some evidence derived from

327 mouse-trapping campaigns also suggests that small mammals are scarcer on Isla Victoria than on

328 nearby continental areas of the National Park (Nuñez et al. 2013). We also understand that we

329 are considering a snapshot of the abundance of terrestrial birds and mammals, although we

330 believe this pattern is likely to be consistent in time.

331

332 It has been suggested that invasive species with no negative impacts on native biodiversity, can

333 be beneficial because they can increase local biodiversity (Thomas \& Palmer 2015) or supply 
334 benefits such as habitat or food to native species (Davis et al. 2011). Some invasive species can

335 also have an important role as dispersers of seeds of native species in their introduced range

336 (Chimera \& Drake 2010). On Isla Victoria C. elaphus, S. scrofa and L. nycthemera are

337 consumers of fleshy fruits and might be contributing to seed dispersal of native plants. However,

338 in our study site non-native species have reached such high proportions (see Fig. 2) that we can

339 hypothesize they are displacing native fauna. The replacement of native fauna by non-native

340 animals can have other important consequences for the functioning of local ecosystems. For

341 example, on Isla Victoria, it has been demonstrated that non-native deer prefer native plants

342 rather than non-natives, a fact that could promote the invasion by non-native conifers (Nuñez et

343 al. 2008). The consumption of fruits of invasive shrubs by non-native animals, for example fruits

344 of Juniperus communis, Rosa rubiginosa or Rubus ulmifolius, can be promoting plant invasions.

345 Furthermore, soil disturbance by S. scrofa can facilitate invasive plant establishment (Barrios-

346 Garcia \& Simberloff 2013). Lastly, both S. scrofa and deer are involved in the dispersal of

347 mycorrhizal fungi that allow colonization by non-native conifers (Nuñez et al. 2013).

348

349 It is difficult to know whether the presence of non-native animals was the driver of native species

350 decline, but based on previous evidence it is likely that at least the successful establishment of

351 the non-natives could have contributed to the decline of the natives. We believe this is likely

352 based on the extremely low capture rate of native vertebrates ( $0.3 \%$ of camera-trapping captures)

353 and the presence of species known to have reduced populations or extinguished species

354 elsewhere (Table 3).

355

356 Recently, Nahuel Huapi National Park has started implementing a management plan for invasive 
357 non-native vertebrates (Disposition 422/2014, Mujica 2014). Specifically, this plan regulates the 358 control through hunting of C. elaphus, D. dama, and S. scrofa on Isla Victoria, Nahuel Huapi

359 National Park. This program allowed the removal of more than 150 individuals during its first

360 year of implementation (unpublished data), and it could represent a first step towards the

361 recovering of native biodiversity on Isla Victoria. We suggest that monitoring through camera

362 trapping using a sampling design similar to ours could be an economic way to evaluate the

363 results of this program. Also, we strongly recommend that a plan for the control and eradication

364 of non-native species on the island should also contemplate $N$. vison and F. domesticus, because

365 of their role as predators of native fauna. Together with the monitoring of terrestrial fauna using

366 camera-trapping, we suggest conducting a monitoring focused on small mammals (rodents and

367 marsupials) using some array of live traps. In addition, active efforts to reintroduce native deer

368 species as $P$. pudu and H. bisulcus could be highly beneficial for their global conservation, given

369 that Isla Victoria has proved to be an ideal place for the acclimatization of herbivores, and that

370 these two species are categorized as vulnerable and endangered respectively by the IUCN.

371 Administrators of protected areas should also take measures to prevent the expansion of invasive

372 species and the entrance of new ones to other regions of Nahuel Huapi National Park. 


\section{Acknowledgments}

375

376 We are very grateful to the National Park Service of Argentina for help with logistics and

377 research permits and to Cau-Cau for help with transportation to the island. N. González, F.

378 Villalba, M. Mansilla and several national park volunteers helped with field work. We also thank

379 C. Chehébar, E. Ramilo, N. Barrios-Garcia, D. Simberloff, D. Hansen, A. Traveset and one

380 anonymous reviewer for useful comments and suggestions on previous drafts of the manuscript.

381 


\section{References}

384

385

386

387

388

389

390

391

392

393

Amico GC, García D, and Rodríguez-Cabal MA. 2008. Spatial structure and scale-dependent microhabitat use of endemic "tapaculos" (Rhinocryptidae) in a temperate forest of southern South America. Ecología Austral 18:169-180.

Azzurro E, Tuset VM, Lombarte A, Maynou F, Simberloff D, Rodríguez-Pérez A, and Solé RV. 2014. External morphology explains the success of biological invasions. Ecology letters $17: 1455-1463$.

Barrios-Garcia MN, and Ballari SA. 2012. Impact of wild boar (Sus scrofa) in its introduced and native range: a review. Biological Invasions 14:2283-2300.

Barrios-Garcia MN, Classen AT, and Simberloff D. 2014. Disparate responses of above-and belowground properties to soil disturbance by an invasive mammal. Ecosphere 5:art44.

Barrios-Garcia MN, Relva MA, and Kitzberger T. 2012. Patterns of use and damage by exotic deer on native plant communities in northwestern Patagonia. European Journal of Wildlife Research 58:137-146.

Barrios-Garcia MN, and Simberloff D. 2013. Linking the pattern to the mechanism: How an introduced mammal facilitates plant invasions. Austral Ecology 38:884-890.

Blackburn TM, Cassey P, Duncan RP, Evans KL, and Gaston KJ. 2004. Avian extinction and mammalian introductions on oceanic islands. Science 305:1955-1958.

Bonesi L, and Palazon S. 2007. The American mink in Europe: status, impacts, and control. Biological Conservation 134:470-483.

Buckland ST, Anderson D, Burnham KP, Laake J, Borchers D, and Thomas L. 2007. Advanced distance sampling: estimating abundance of biological populations: Oxford University 
Press London.

407 Contreras JR. 1973. Modalidades de la muda del pelaje en el ratón colilargo Oryzomys

408 longicaudatus Philippi (Landbeck). Physis 32:191-197.

Coomes DA, Allen RB, Forsyth DM, and Lee WG. 2003. Factors preventing the recovery of New Zealand forests following control of invasive deer. Conservation Biology 17:450-

Chimera CG, and Drake DR. 2010. Patterns of seed dispersal and dispersal failure in a Hawaiian dry forest having only introduced birds. Biotropica 42:493-502.

Daciuk J. 1978a. Aclimatación de aves y mamíferos en el parque nacional Nahuel Huapi (Prov. de Neuquén y Río Negro, Argentina), con especial referencia de los faisánidos. Anales de Parques Nacionales 14:96-104.

Daciuk J. 1978b. Evaluación preliminar de la fauna de vertebrados de la isla Victoria (Parque Nacional Nahuel Huapi, Prov. de Neuquén y Río Negro, Argentina). Anales de Parques Nacionales 14:8795.

Davis MA, Chew MK, Hobbs RJ, Lugo AE, Ewel JJ, Vermeij GJ, Brown JH, Rosenzweig ML, Gardener MR, and Carroll SP. 2011. Don't judge species on their origins. Nature 474:153-154.

Driscoll CA, Menotti-Raymond M, Roca AL, Hupe K, Johnson WE, Geffen E, Harley EH, Delibes M, Pontier D, and Kitchener AC. 2007. The Near Eastern origin of cat domestication. Science 317:519-523.

Fasola L, Muzio J, Chehébar C, Cassini M, and Macdonald DW. 2011. Range expansion and prey use of American mink in Argentinean Patagonia: dilemmas for conservation. European Journal of Wildlife Research 57:283-294. 
429 Funasaki GY, Lai P-Y, Nakahara LM, Beardsley JW, and Ota AK. 1988. A review of biological 430 control introductions in Hawaii: 1890 to 1985. Hawaiian Entomological Society 28:105$431 \quad 160$.

432 Gantchoff MG, and Belant JL. 2015. Anthropogenic and environmental effects on invasive 433 mammal distribution in northern Patagonia, Argentina. Mammalian Biology 80:54-58.

434 Gantchoff MG, Belant JL, and Masson DA. 2014. Occurrence of invasive mammals in southern $435 \quad$ Nahuel Huapi National Park. Studies on Neotropical Fauna and Environment 48.

436 Grigera D, Úbeda CA, and Cali S. 1994. Caracterización ecológica de la asamblea de tetrápodos del Parque y Reserva Nacional Nahuel Huapi, Argentina. Revista Chilena de Historia Natural 67:273-298.

Hobbs RJ, and Huenneke LF. 1992. Disturbance, diversity, and invasion: implications for conservation. Conservation Biology 6:324-337.

Hulme PE, Bacher S, Kenis M, Klotz S, Kühn I, Minchin D, Nentwig W, Olenin S, Panov V, Pergl J, Pyšek P, Roques A, Sol D, Solarz W, and Vilà M. 2008. Grasping at the routes of biological invasions: a framework for integrating pathways into policy. Journal of Applied Ecology 45:403-414.

Kays R, Kranstauber B, Jansen P, Carbone C, Rowcliffe M, Fountain T, and Tilak S. 2011. Camera traps as sensor networks for monitoring animal communities. International Journal of Research and Reviews 1:811-818.

Koutché V. 1942. Estación forestal de Puerto Achorena, Isla Victoria; su organización y trabajos. Buenos Aires: Ministerio de Agricultura, Dirección de Parques Nacionales.

450 Lambertucci SA, and Speziale KL. 2011. Protecting invaders for profit. Science 332.

451 Lambertucci SA, Trejo A, Di Martino S, Sánchez-Zapata JA, Donázar JA, and Hiraldo F. 2009. 
Spatial and temporal patterns in the diet of the Andean condor: ecological replacement of native fauna by exotic species. Animal Conservation 12:338-345.

454 Lantschner M-V, Rusch V, and Hayes JP. 2012. Do exotic pine plantations favour the spread of 455 invasive herbivorous mammals in Patagonia? Austral Ecology 38:338-345.

456 Lantschner MV, and Rusch V. 2007. Impacto de diferentes disturbios antrópicos sobre las 457 comunidades de aves de bosques y matorrales de Nothofagus antarctica en el NO $458 \quad$ Patagónico. Ecología Austral 17:99-112.

459 Lever C. 2005. Naturalized Birds of the World: Poyser.

460 Leverington F, Costa KL, Pavese H, Lisle A, and Hockings M. 2010. A global analysis of 461 protected area management effectiveness. Environmental Management 46:685-698.

462 Lockwood JL, Cassey P, and Blackburn T. 2005. The role of propagule pressure in explaining 463 species invasions. Trends in Ecology \& Evolution 20:223-228.

464 Loss SR, Will T, and Marra PP. 2013. The impact of free-ranging domestic cats on wildlife of 465 the United States. Nature Communications 4:1396.

MaCdonald DW, and Harrington LA. 2003. The American mink: The triumph and tragedy of adaptation out of context. New Zealand Journal of Zoology 30:421-441.

MacDougall AS, Gilbert B, and Levine JM. 2009. Plant invasions and the niche. Journal of Ecology 97:609-615.

Marques TA, Thomas L, Fancy SG, Buckland ST, and Handel C. 2007. Improving estimates of bird density using multiple-covariate distance sampling. The Auk 124:1229-1243.

Massei G, and Genov PV. 2004. The environmental impact of wild boar. Galemys 16:135-145. 
on island endangered vertebrates. Global Change Biology 17:3503-3510.

476

477

478

479

480

481

482

484

485

486

487

488

489

490

491

492

493

494

495

496

497

Merino ML, Carpinetti BN, and Abba AM. 2009. Invasive mammals in the national parks system of Argentina. Natural Areas Journal 29:42-49.

Mujica DH. 2014. Disposición 422/2014: Plan piloto de caza control de ciervo colorado (Cervus elaphus), ciervo dama (Dama dama) y jabalí europeo (Sus scrofa) en la isla Victoria, Parque Nacional Nahuel Huapi. San Carlos de Bariloche: Departamento de Conservación y Educación Ambiental, Parque Nacional Nahuel Huapi.

Naughton-Treves L, Holland MB, and Brandon K. 2005. The role of protected areas in conserving biodiversity and sustaining local livelihoods. Annual Reviews of Environment and Resources 30:219-252.

Novaro AJ, Funes MC, and Walker SR. 2000. Ecological extinction of native prey of a carnivore assemblage in Argentine Patagonia. Biological Conservation 92:25-33.

Nuñez MA, Hayward J, Horton TR, Amico GC, Dimarco RD, Barrios-Garcia MN, and Simberloff D. 2013. Exotic mammals disperse exotic fungi that promote invasion by exotic trees. PLoS ONE 8.

Nuñez MA, Relva MA, and Simberloff D. 2008. Enemy release or invasional meltdown? Deer preference for exotic and native trees on Isla Victoria, Argentina. Austral Ecology 33:317-323.

Nuñez MA, and Simberloff D. 2005. Invasive species and the cultural keystone species concept. Ecology and Society 10.

Pozzi CM, and Ramilo E. 2011. El cormorán imperial en el lago Nahuel Huapi: historia y nuevos estudios. Macroscopia 2:12-14.

Reichard SH. 1994. Assessing the potential of invasiveness in woody plants introduced to North 
America. University of Washington.

499

500

501

502

503

504

Relva MA, Nuñez MA, and Simberloff D. 2010. Introduced deer reduce native plant cover and facilitate invasion of non-native tree species: evidence for invasional meltdown. Biological Invasions 12:303-311.

Relva MA, Westerholm CL, and Kitzberger T. 2009. Effects of introduced ungulates on forest understory communities in northern Patagonia are modified by timing and severity of stand mortality. In: van der Valk AG, ed. Forest Ecology: Springer Netherlands, 11-22.

Rowcliffe JM, Field J, Turvey ST, and Carbone C. 2008. Estimating animal density using camera traps without the need for individual recognition. Journal of Applied Ecology 45:1228-1236.

Rowcliffe M, Carbone C, Jansen PA, Kays R, and Kranstauber B. 2011. Quantifying the sensitivity of camera traps: an adapted distance sampling approach. Methods in Ecology and Evolution 2:464-476.

Sanguinetti J, Buria L, Malmierca L, Valenzuela AEJ, Núñez C, Pastore H, Chauchard L, Ferreyra N, Massaccesi G, GALLO E, and Chehébar C. 2014. Manejo de especies exóticas invasoras en Patagonia, Argentina: Priorización, logros y desafíos de integración entre ciencia y gestión identificados desde la Administración de Parques Nacionales. Ecología Austral 24:183-192.

Simberloff D, Martin J-L, Genovesi P, Maris V, Wardle DA, Aronson J, Courchamp F, Galil B, García-Berthou E, Pascal M, Pyšek P, Sousa R, Tabacchi E, and Vilà M. 2013. Impacts of biological invasions: what's what and the way forward. Trends in Ecology \& Evolution 28:58-66.

Simberloff D, Relva MA, and Nuñez M. 2002. Gringos en el bosque: Introduced tree invasion in 
a native Nothofagus/Austrocedrus forest. Biological Invasions 4:35-53.

522 Simberloff D, Relva MA, and Nuñez M. 2003. Introduced species and management of a Nothofagus/Austrocedrus forest. Environmental Management 31:263-275.

524 Skewes O, Rodriguez R, and Jaksic FM. 2007. Ecología trófica del jabalí europeo (Sus scrofa) 525 silvestre en Chile. Revista Chilena de Historia Natural 80:295-307.

526 Thomas CD, and Palmer G. 2015. Non-native plants add to the British flora without negative 527 consequences for native diversity. Proceedings of the National Academy of Sciences $112: 4387-4392$.

529 Woinarski JCZ, Burbidge AA, and Harrison PL. 2015. Ongoing unraveling of a continental 530 fauna: Decline and extinction of Australian mammals since European settlement.

$531 \quad$ Proceedings of the National Academy of Sciences 112:4531-4540.

532 Wood JR, Dickie IA, Moeller HV, Peltzer DA, Bonner KI, Rattray G, and Wilmshurst JM. 2015.

533 Novel interactions between non-native mammals and fungi facilitate establishment of 534 invasive pines. Journal of Ecology 103:121-129.

535 Zenni RD, and Nuñez MA. 2013. The elephant in the room: the role of failed invasions in 536 understanding invasion biology. Oikos 122:801-815. 
538 Table 1: Introduced and naturalized terrestrial vertebrates on Isla Victoria. List of

539 introduced and naturalized terrestrial vertebrates on Isla Victoria, Nahuel Huapi National Park;

540 their estimated date of introduction and current status. Pudu pudu was the only native species

541 introduced to the island.

Species

Birds

Pavo cristatus
Chrysolophus pictus
Chrysolophus amhersti
Lophura nycthemera
Phasianus colchicus
Phasianus sp.
Numida meleagris

Mammals

$\begin{array}{ll}\text { Rattus sp. } & \text { Unknown (Daciuk 1978a) } \\ \text { Mus sp. } & \text { Unknown (Daciuk 1978a) } \\ \text { Cervus elaphus } & \text { 1917-1922 (Daciuk 1978a) } \\ \text { Cervus axis } & \text { 1917-1922 (Daciuk 1978a) } \\ \text { Dama dama } & \text { 1917-1922 (Daciuk 1978a) } \\ \text { Pudu pudu (native) } & 1951-1959 \text { (Daciuk 1978a) } \\ \text { Sus scrofa } & \sim 1999, \text { natural spread from } \\ & \text { continent (Simberloff et al. 2003) } \\ \text { Neovison vison } & \text { Unknown, natural spread from } \\ & \text { continent (Pozzi \& Ramilo 2011) } \\ & \text { Unknown (Daciuk 1978a) }\end{array}$

\section{Current status on the island}

Extinct

Extinct

Extinct

Naturalized

Extinct

Extinct

Extinct

Naturalized

Naturalized

Naturalized (feral) 
544 Table 2: Original assemblage of native terrestrial vertebrates on Isla Victoria. List of

545 species of the original assemblage of native terrestrial vertebrates on Isla Victoria, Nahuel Huapi

546 National Park according to historical records and their current status.

Species

Tachymenis chilensis

Birds

Scelorchilus rubecula

Pteroptochos tarnii

Mammals

Dromiciops gliroides

Oryzomys longicaudatus

(Contreras 1973)

Irenomys tarsalis

Hippocamelus bisulcus
(Daciuk 1978b)

Not available

(Daciuk 1978b)

Not available

(Daciuk 1978b)

(Daciuk 1978b)

(Koutché 1942)
Current status on Isla

Victoria

Present (personal observation)

Present (personal observation)

Present (this study)

Probably Extinct

Present (D. Rivarola, personal

communication)

Present (this study)

Present (D. Rivarola, personal

communication)

Extinct 
548 Table 3: Antecedents of invasion of non-native species detected on Isla Victoria. List of non-

549 native species detected on Isla Victoria and their known native range, invaded regions and

550 impacts reported.

\begin{tabular}{|c|c|c|c|c|}
\hline Species & Native range & Invaded regions & Known impacts & Reference(s) \\
\hline Cervus elaphus & Eurasia & $\begin{array}{l}\text { North and South } \\
\text { America, New } \\
\text { Zealand and } \\
\text { Australia }\end{array}$ & $\begin{array}{l}\text { Impact on natural } \\
\text { regeneration of the } \\
\text { native forest and } \\
\text { facilitation of non- } \\
\text { native plant growth. } \\
\text { Dispersal of non- } \\
\text { native } \\
\text { ectomycorrhizal } \\
\text { fungi that promote } \\
\text { Pinaceae invasions. } \\
\text { Competitive } \\
\text { displacement of } \\
\text { native deer. }\end{array}$ & $\begin{array}{l}\text { (Barrios-Garcia et al. } \\
\text { 2012; Coomes et al. } \\
\text { 2003; Nuñez et al. } \\
\text { 2013; Nuñez et al. } \\
\text { 2008; Relva et al. } \\
\text { 2010; Wood et al. } \\
\text { 2015) }\end{array}$ \\
\hline Dama dama & Eurasia & $\begin{array}{l}\text { North and South } \\
\text { America, South } \\
\text { Africa, New } \\
\text { Zealand and } \\
\text { Australia. }\end{array}$ & $\begin{array}{l}\text { Impact on natural } \\
\text { regeneration of the } \\
\text { native forest and } \\
\text { facilitation of non- } \\
\text { native plant growth. } \\
\text { Dispersal of non- } \\
\text { native } \\
\text { ectomycorrhizal } \\
\text { fungi that promote } \\
\text { Pinaceae invasions. }\end{array}$ & $\begin{array}{l}\text { (Barrios-Garcia et al. } \\
\text { 2012; Nuñez et al. } \\
\text { 2013; Nuñez et al. } \\
\text { 2008; Relva et al. } \\
\text { 2010) }\end{array}$ \\
\hline
\end{tabular}




\begin{tabular}{|c|c|c|c|c|}
\hline & & & $\begin{array}{l}\text { Competitive } \\
\text { displacement of } \\
\text { native deer. }\end{array}$ & \\
\hline Sus scrofa & $\begin{array}{l}\text { Eurasia, north of } \\
\text { Africa }\end{array}$ & $\begin{array}{l}\text { Widely distributed } \\
\text { worldwide, it is } \\
\text { present on all } \\
\text { continents except } \\
\text { Antarctica, and } \\
\text { many oceanic } \\
\text { islands }\end{array}$ & $\begin{array}{l}\text { Change in soil } \\
\text { structure and } \\
\text { processes, reduction } \\
\text { of plant cover, } \\
\text { decreasing of plant } \\
\text { species diversity, } \\
\text { alteration of plant } \\
\text { Pinaceae invasions. } \\
\text { Alteration of water } \\
\text { fuality and } \\
\text { predation of seeds of } \\
\text { native species, } \\
\text { ectomycorrhizal } \\
\text { Dispersal of non- } \\
\text { increase of non- } \\
\text { and resithes } \\
\text { native plants } \\
\text { abundance. }\end{array}$ & $\begin{array}{l}\text { (Barrios-Garcia \& } \\
\text { Ballari 2012; Barrios- } \\
\text { Garcia et al. 2014; } \\
\text { Barrios-Garcia \& } \\
\text { Simberloff 2013; } \\
\text { Massei \& Genov } \\
\text { 2004; Nuñez et al. } \\
\text { 2013) }\end{array}$ \\
\hline
\end{tabular}




\begin{tabular}{|c|c|c|c|c|}
\hline & & & chemistry. & \\
\hline $\begin{array}{l}\text { Lophura } \\
\text { nycthemera }\end{array}$ & Southeast Asia & $\begin{array}{l}\text { Argentina and } \\
\text { Germany }\end{array}$ & $\begin{array}{l}\text { Competition with } \\
\text { native fauna, seed } \\
\text { dispersal of non- } \\
\text { native plants. }\end{array}$ & $\begin{array}{l}\text { (Daciuk 1978a; Lever } \\
\text { 2005) }\end{array}$ \\
\hline $\begin{array}{l}\text { Felis } \\
\text { domesticus }\end{array}$ & $\begin{array}{l}\text { Domesticated from } \\
\text { the Wildcat (F.s. } \\
\text { lybica), probably } \\
9-10,000 \text { years ago } \\
\text { in the Fertile } \\
\text { Crescent region of } \\
\text { the Near East. }\end{array}$ & $\begin{array}{l}\text { Widely distributed } \\
\text { worldwide, it is } \\
\text { present on all } \\
\text { continents except } \\
\text { Antarctica, and } \\
\text { many oceanic } \\
\text { islands }\end{array}$ & $\begin{array}{l}\text { Predation on native } \\
\text { fauna including } \\
\text { reptiles, birds and } \\
\text { mammals. } \\
\text { Responsible for many } \\
\text { extinctions on } \\
\text { oceanic islands. }\end{array}$ & $\begin{array}{l}\text { (Driscoll et al. 2007; } \\
\text { Loss et al. 2013; } \\
\text { Medina et al. 2011; } \\
\text { Woinarski et al. } \\
\text { 2015) }\end{array}$ \\
\hline Neovison vison & North America & $\begin{array}{l}\text { Argentina, Chile, } \\
\text { widely distributed } \\
\text { throughout Eurasia }\end{array}$ & $\begin{array}{l}\text { Predation on native } \\
\text { fauna including } \\
\text { mammals, birds, } \\
\text { amphibia and } \\
\text { Crustacea. } \\
\text { Competition with } \\
\text { native minks. }\end{array}$ & $\begin{array}{l}\text { (Bonesi \& Palazon } \\
\text { 2007; MaCdonald \& } \\
\text { Harrington 2003) }\end{array}$ \\
\hline
\end{tabular}

551 
553 Fig. 1: Study area. Map of Isla Victoria showing the main ports and the transects for camera

554 trapping and censuses. A solid line indicates that both camera trapping and censuses were

555 conducted; a dashed line indicates that only direct censuses were conducted.

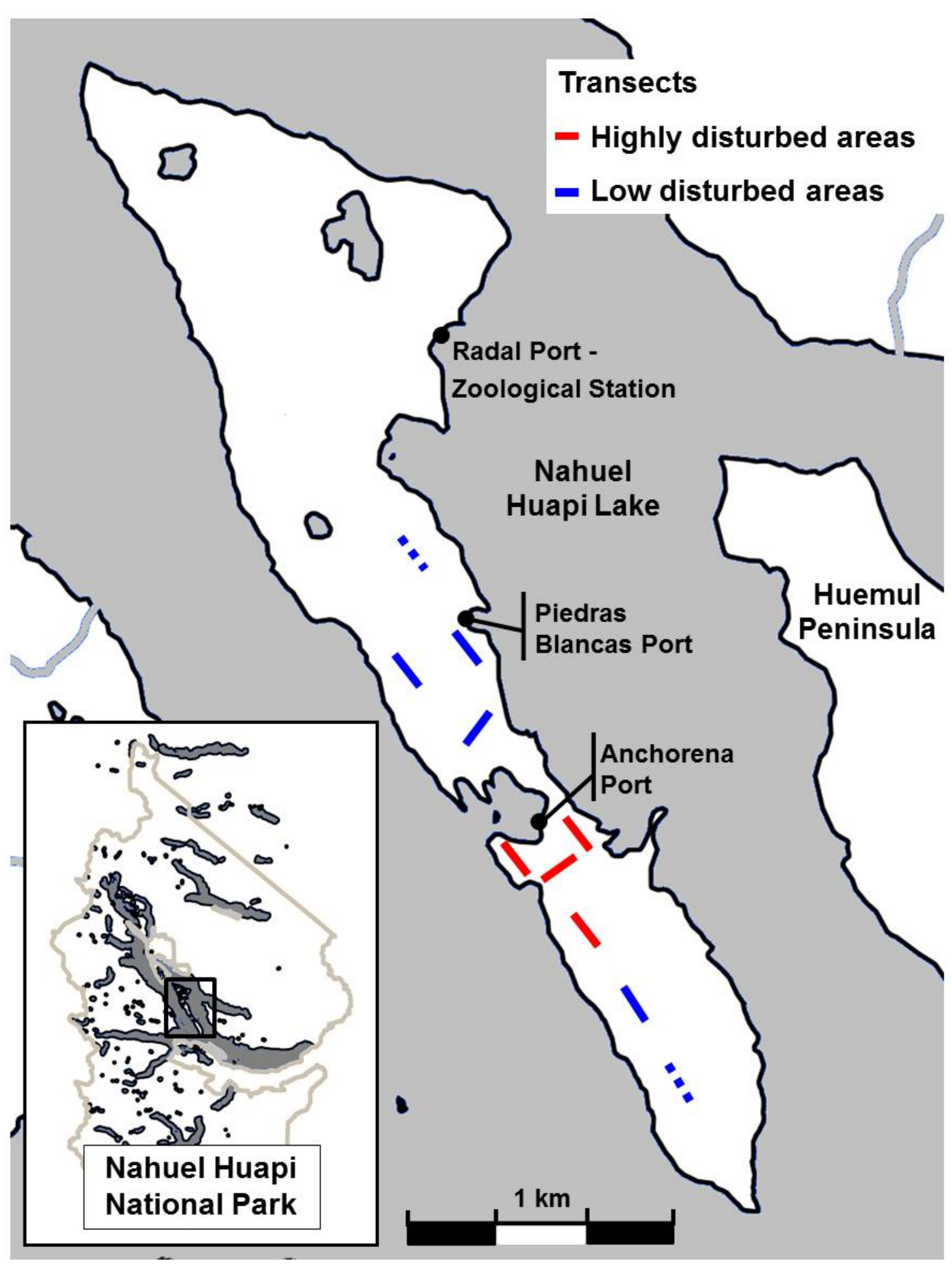


Fig. 2: Camera trapping captures of terrestrial species. Total number of captures

558 obtained by camera trapping for each terrestrial species, including species reported for the island in Daciuk (1978b) and not detected in this study.

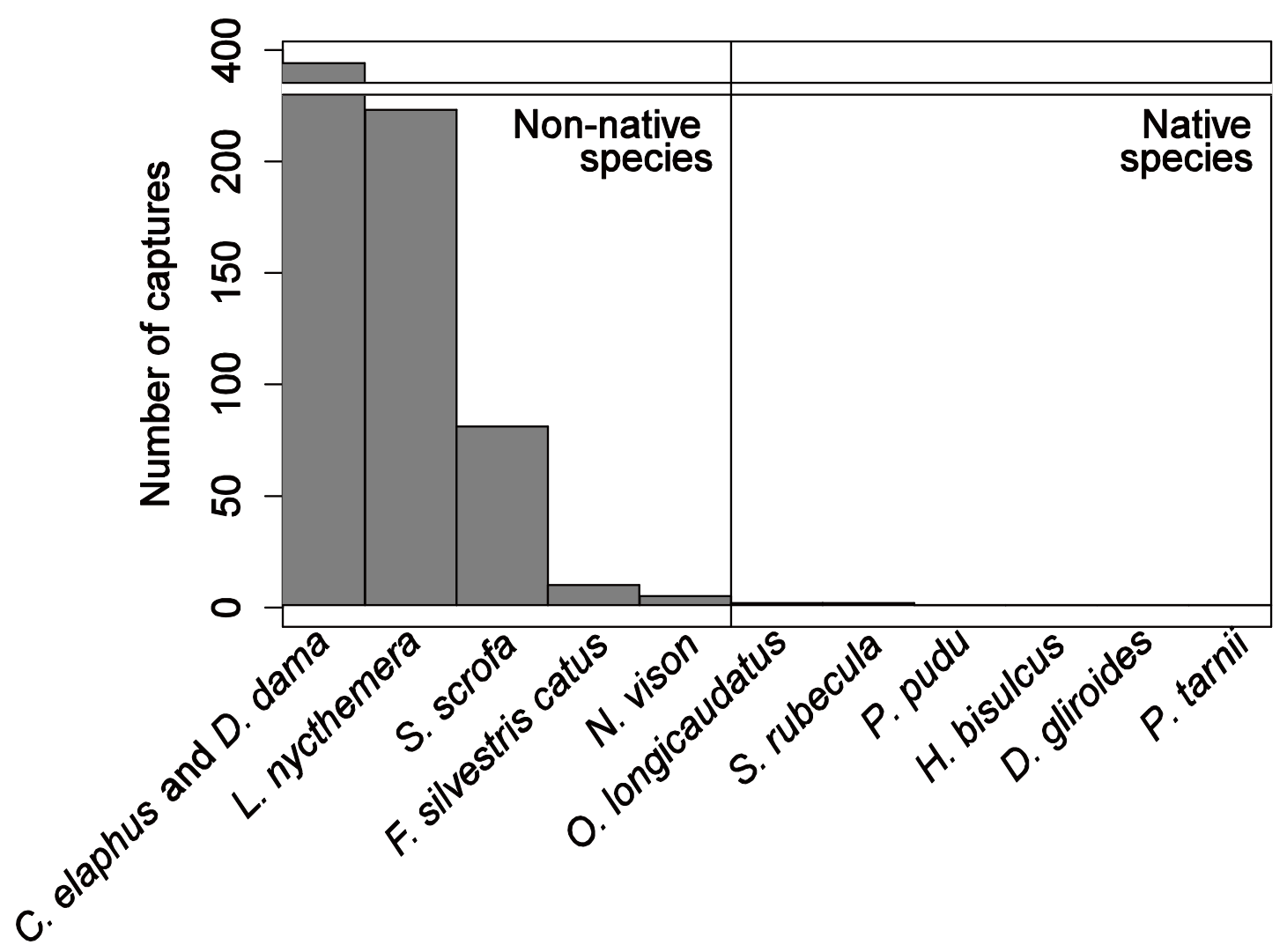


562 Fig. 3: Habitat use. Relative abundance index (RAI) for the four species most frequently

563 captured in areas with high and low levels of disturbance. Ns represent the total number of

564 captures obtained for each species. An asterisk indicate species with differential use of low and

565 high-disturbed habitats.

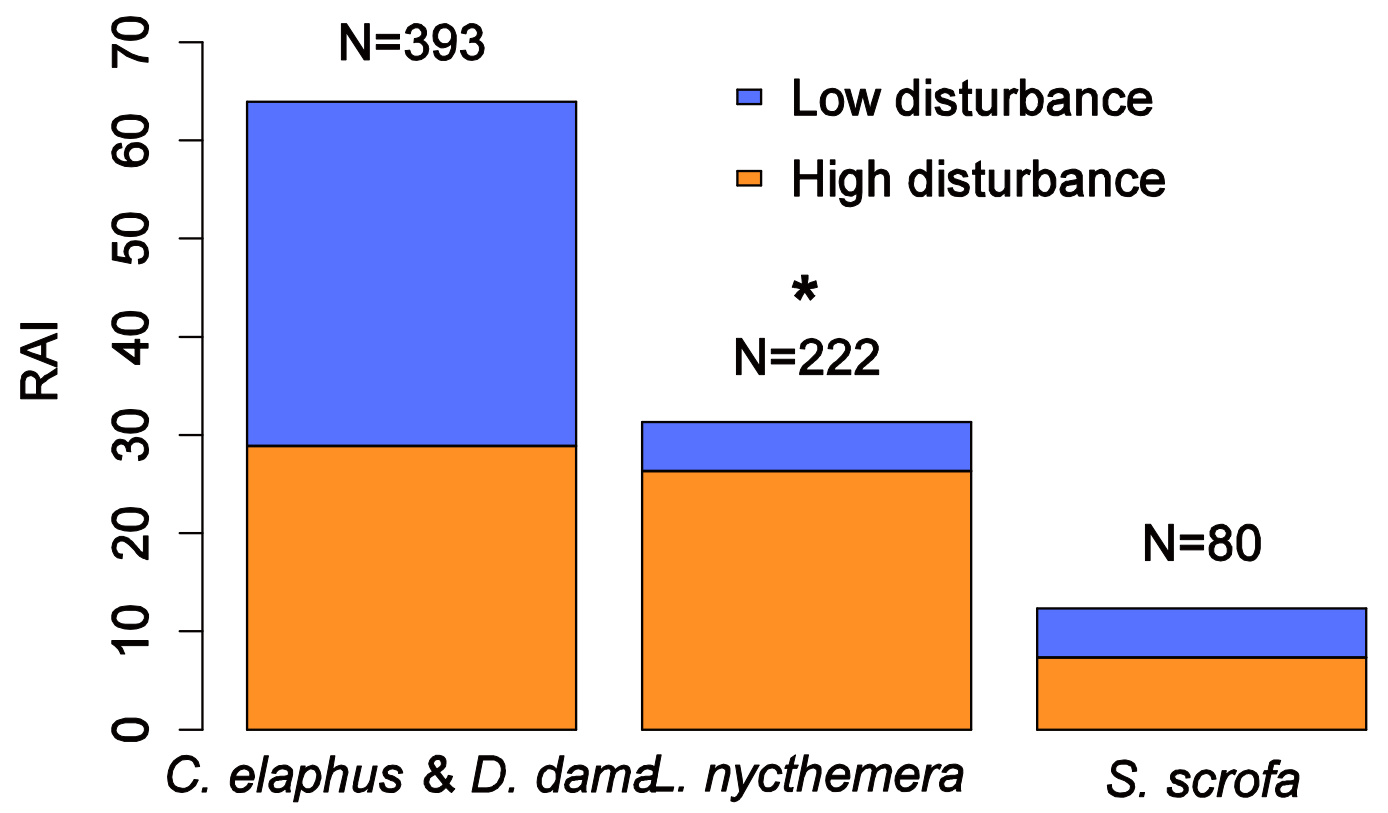


568 Fig. 4: Detectability of animals. Histograms of observed distances and fitted detection functions

569 for L. nycthemera (a and b respectively, N=33), S. rubecula (c and d, N=36), C. elaphus and D.

570 dama (e and f, $\mathrm{N}=15$ ), and $S$. scrofa (g and h, N=7).
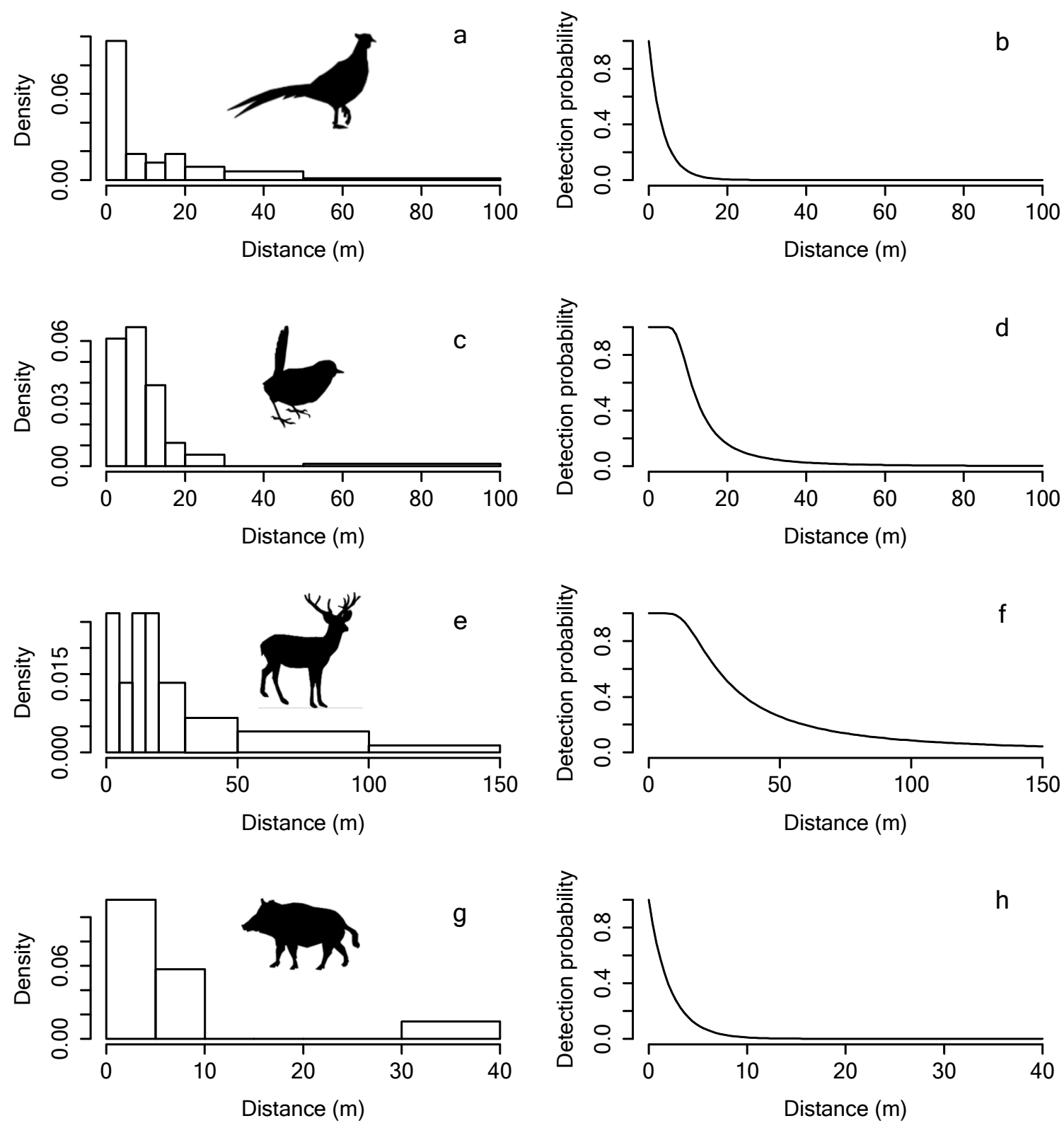

571

572

573 
Table $\mathbf{1}$ (on next page)

Introduced and naturalized terrestrial vertebrates on Isla Victoria

List of introduced and naturalized terrestrial vertebrates on Isla Victoria, Nahuel Huapi National Park; their estimated date of introduction and current status. Pudu pudu was the only native species introduced to the island. 


\section{Species}

Birds

Pavo cristatus
Chrysolophus pictus
Chrysolophus amhersti
Lophura nycthemera
Phasianus colchicus
Phasianus sp.
Numida meleagris

Mammals

$\begin{array}{ll}\text { Rattus sp. } & \text { Unknown (Daciuk 1978a) } \\ \text { Mus sp. } & \text { Unknown (Daciuk 1978a) } \\ \text { Cervus elaphus } & \text { 1917-1922 (Daciuk 1978a) } \\ \text { Cervus axis } & \text { 1917-1922 (Daciuk 1978a) } \\ \text { Dama dama } & \text { 1917-1922 (Daciuk 1978a) } \\ \text { Pudu pudu (native) } & \text { 1951-1959 (Daciuk 1978a) } \\ \text { Sus scrofa } & \sim 1999, \text { natural spread from } \\ & \text { continent (Simberloff et al. 2003) } \\ \text { Neovison vison } & \text { Unknown, natural spread from } \\ & \text { continent (Pozzi \& Ramilo 2011) } \\ \text { Felis domesticus } & \text { Unknown (Daciuk 1978a) }\end{array}$

\section{Current status on the island}

Extinct

Extinct

Extinct

Naturalized

Extinct

Extinct

Extinct

Unknown

Unknown

Naturalized

Extinct

Naturalized

Extinct

Naturalized

Naturalized

Naturalized (feral) 
Table 2 (on next page)

Original assemblage of native terrestrial vertebrates on Isla Victoria

List of species of the original assemblage of native terrestrial vertebrates on Isla Victoria, Nahuel Huapi National Park according to historical records and their current status. 
Species

Reptiles

Liolaemus spp.

(Daciuk 1978b)

Tachymenis chilensis

Not available

Birds

Scelorchilus rubecula

Pteroptochos tarnii

Mammals

$$
\text { Dromiciops gliroides }
$$

(Daciuk 1978b)

(Daciuk 1978b)

(Daciuk 1978b)

(Contreras 1973)

Not available

Irenomys tarsalis

Hippocamelus bisulcus

(Koutché 1942)

\author{
Present (personal observation) \\ Present (personal observation)
}

Present (this study)

Probably Extinct

Present (D. Rivarola, personal communication)

Present (this study)

Present (D. Rivarola, personal

communication)

Extinct 
Table 3(on next page)

Antecedents of invasion of non-native species detected on Isla Victoria

List of non-native species detected on Isla Victoria and their known native range, invaded regions and impacts reported. 


\begin{tabular}{|c|c|c|c|c|}
\hline Species & Native range & Invaded regions & Known impacts & Reference(s) \\
\hline Cervus elaphus & Eurasia & $\begin{array}{l}\text { North and South } \\
\text { America, New } \\
\text { Zealand and } \\
\text { Australia }\end{array}$ & $\begin{array}{l}\text { Impact on natural } \\
\text { regeneration of the } \\
\text { native forest and } \\
\text { facilitation of non- } \\
\text { native plant growth. } \\
\text { Dispersal of non- } \\
\text { native } \\
\text { ectomycorrhizal } \\
\text { fungi that promote } \\
\text { Pinaceae invasions. } \\
\text { Competitive } \\
\text { displacement of } \\
\text { native deer. }\end{array}$ & $\begin{array}{l}\text { (Barrios-Garcia et al. } \\
\text { 2012; Coomes et al. } \\
\text { 2003; Nuñez et al. } \\
\text { 2013; Nuñez et al. } \\
\text { 2008; Relva et al. } \\
\text { 2010; Wood et al. } \\
\text { 2015) }\end{array}$ \\
\hline Dama dama & Eurasia & $\begin{array}{l}\text { North and South } \\
\text { America, South } \\
\text { Africa, New } \\
\text { Zealand and } \\
\text { Australia. }\end{array}$ & $\begin{array}{l}\text { Impact on natural } \\
\text { regeneration of the } \\
\text { native forest and } \\
\text { facilitation of non- } \\
\text { native plant growth. } \\
\text { Dispersal of non- } \\
\text { native } \\
\text { ectomycorrhizal } \\
\text { fungi that promote } \\
\text { Pinaceae invasions. } \\
\text { Competitive } \\
\text { displacement of } \\
\text { native deer. }\end{array}$ & $\begin{array}{l}\text { (Barrios-Garcia et al. } \\
\text { 2012; Nuñez et al. } \\
\text { 2013; Nuñez et al. } \\
\text { 2008; Relva et al. } \\
\text { 2010) }\end{array}$ \\
\hline Sus scrofa & Eurasia, north of & Widely distributed & Change in soil & (Barrios-Garcia \& \\
\hline
\end{tabular}




\begin{tabular}{|c|c|c|c|c|}
\hline & Africa & $\begin{array}{l}\text { worldwide, it is } \\
\text { present on all } \\
\text { continents except } \\
\text { Antarctica, and } \\
\text { many oceanic } \\
\text { islands }\end{array}$ & 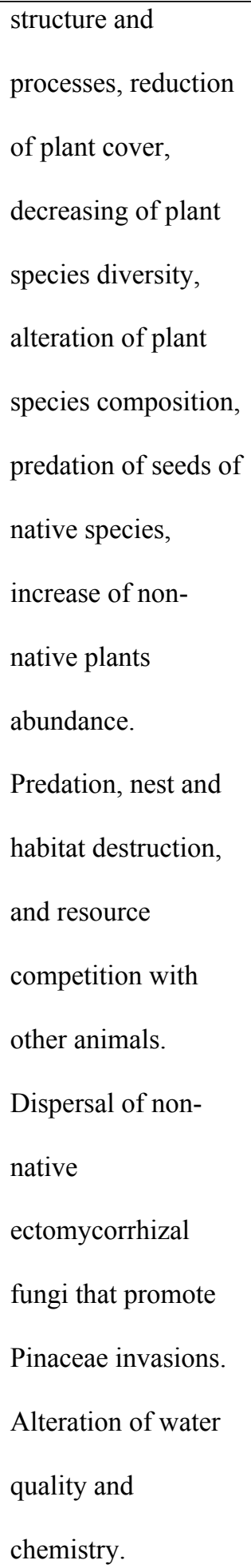 & $\begin{array}{l}\text { Ballari 2012; Barrios- } \\
\text { Garcia et al. 2014; } \\
\text { Barrios-Garcia \& } \\
\text { Simberloff 2013; } \\
\text { Massei \& Genov } \\
\text { 2004; Nuñez et al. } \\
\text { 2013) }\end{array}$ \\
\hline $\begin{array}{l}\text { Lophura } \\
\text { nycthemera }\end{array}$ & Southeast Asia & $\begin{array}{l}\text { Argentina and } \\
\text { Germany }\end{array}$ & $\begin{array}{l}\text { Competition with } \\
\text { native fauna, seed } \\
\text { dispersal of non- }\end{array}$ & $\begin{array}{l}\text { (Daciuk 1978a; Lever } \\
\text { 2005) }\end{array}$ \\
\hline
\end{tabular}




\begin{tabular}{|c|c|c|c|c|}
\hline & & & native plants. & \\
\hline $\begin{array}{l}\text { Felis } \\
\text { domesticus }\end{array}$ & $\begin{array}{l}\text { Domesticated from } \\
\text { the Wildcat (F.s. } \\
\text { lybica), probably } \\
9-10,000 \text { years ago } \\
\text { in the Fertile } \\
\text { Crescent region of } \\
\text { the Near East. }\end{array}$ & $\begin{array}{l}\text { Widely distributed } \\
\text { worldwide, it is } \\
\text { present on all } \\
\text { continents except } \\
\text { Antarctica, and } \\
\text { many oceanic } \\
\text { islands }\end{array}$ & $\begin{array}{l}\text { Predation on native } \\
\text { fauna including } \\
\text { reptiles, birds and } \\
\text { mammals. } \\
\text { Responsible for many } \\
\text { extinctions on } \\
\text { oceanic islands. }\end{array}$ & $\begin{array}{l}\text { (Driscoll et al. 2007; } \\
\text { Loss et al. 2013; } \\
\text { Medina et al. 2011; } \\
\text { Woinarski et al. } \\
2015 \text { ) }\end{array}$ \\
\hline Neovison vison & North America & $\begin{array}{l}\text { Argentina, Chile, } \\
\text { widely distributed } \\
\text { throughout Eurasia }\end{array}$ & $\begin{array}{l}\text { Predation on native } \\
\text { fauna including } \\
\text { mammals, birds, } \\
\text { amphibia and } \\
\text { Crustacea. } \\
\text { Competition with } \\
\text { native minks. }\end{array}$ & $\begin{array}{l}\text { (Bonesi \& Palazon } \\
\text { 2007; MaCdonald \& } \\
\text { Harrington 2003) }\end{array}$ \\
\hline
\end{tabular}

1

2 
Figure 1 (on next page)

Study area

Map of Isla Victoria showing the main ports and the transects for camera trapping and censuses. A solid line indicates that both camera trapping and censuses were conducted; a dashed line indicates that only direct censuses were conducted. 


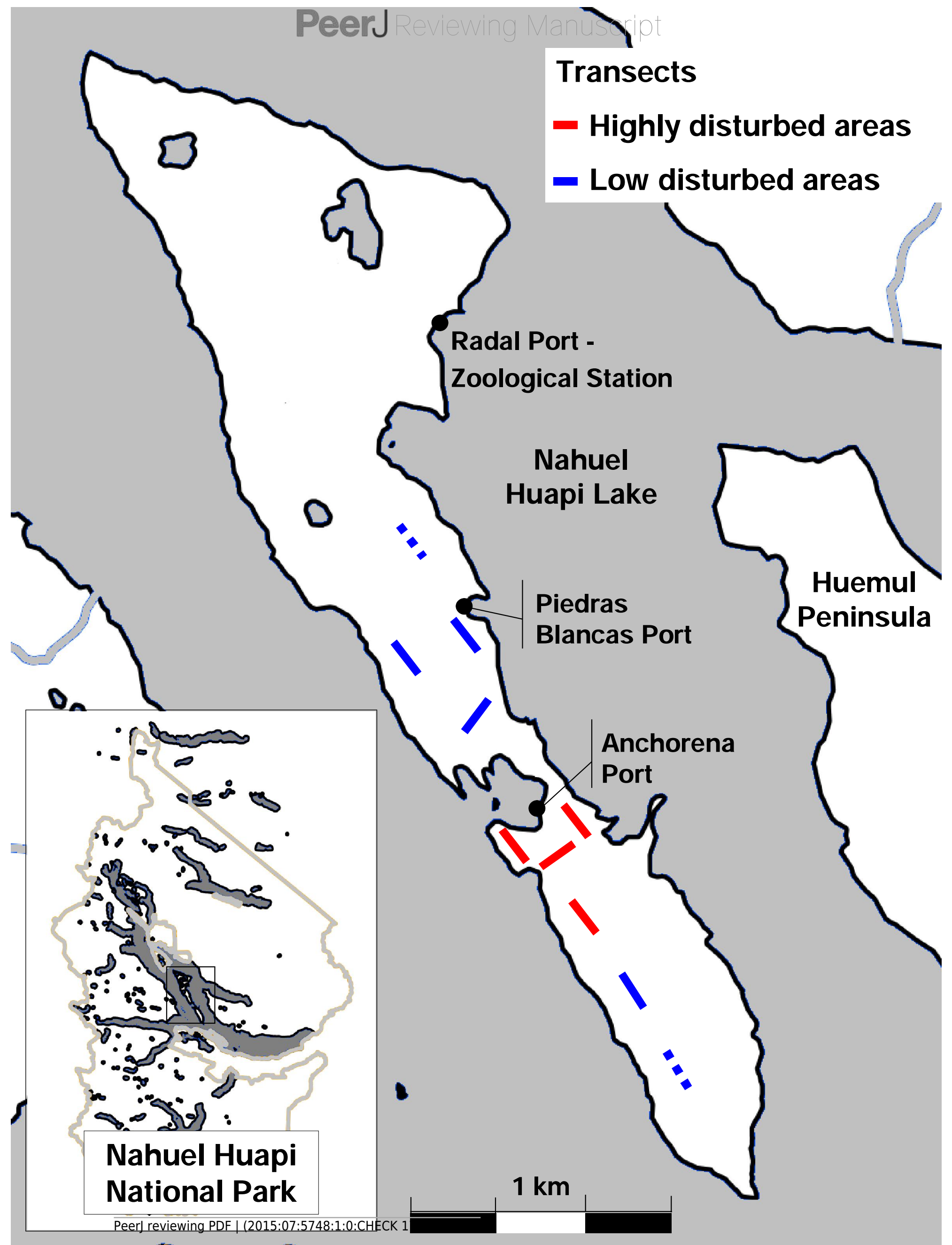


2

Camera trapping captures of terrestrial species

Total number of captures obtained by camera trapping for each terrestrial species, including species reported for the island in Daciuk (1978b) and not detected in this study.

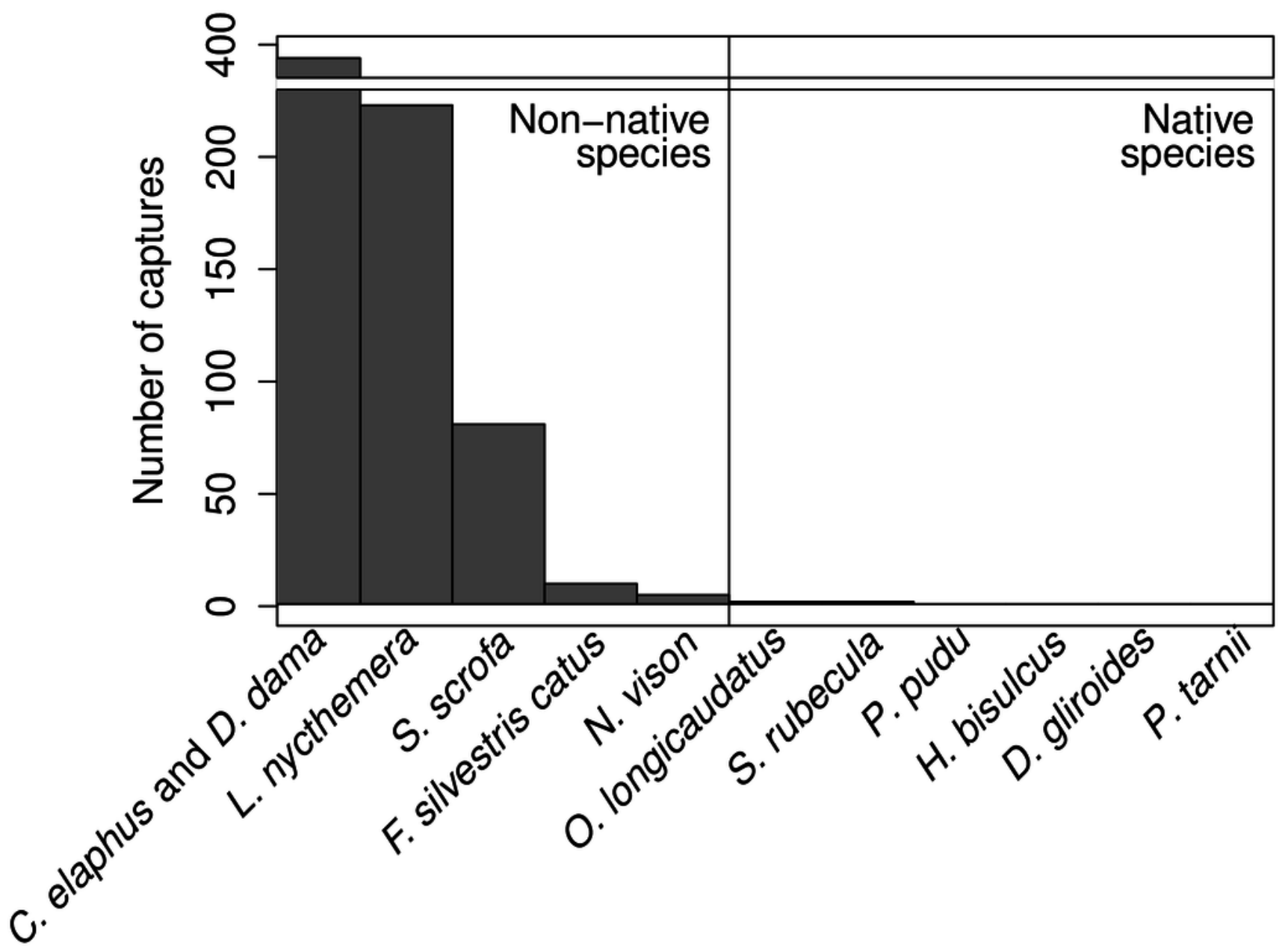




\section{3}

Habitat use

Relative abundance index (RAl) for the four species most frequently captured in areas with high and low levels of disturbance. Ns represent the total number of captures obtained for each species. An asterisk indicate species with differential use of low and high-disturbed habitats.

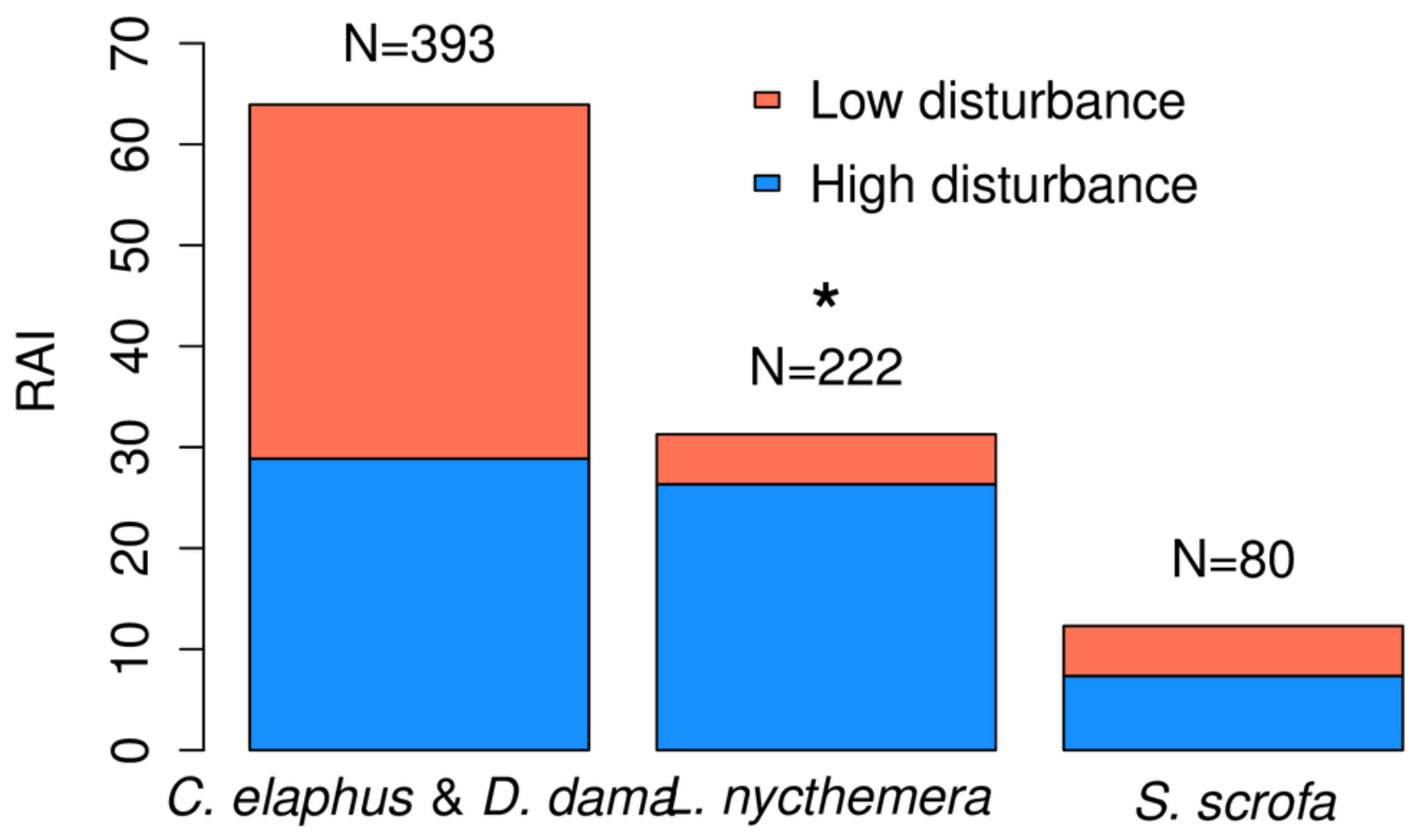


4

Detectability of animals

Histograms of observed distances and fitted detection functions for $L$. nycthemera ( $a$ and $b$ respectively, $\mathrm{N}=33$ ), $S$. rubecula (c and $d, N=36$ ), $C$. elaphus and $D$. dama (e and $f, N=15$ ), and S. scrofa (g and $\mathrm{h}, \mathrm{N}=7$ ). 

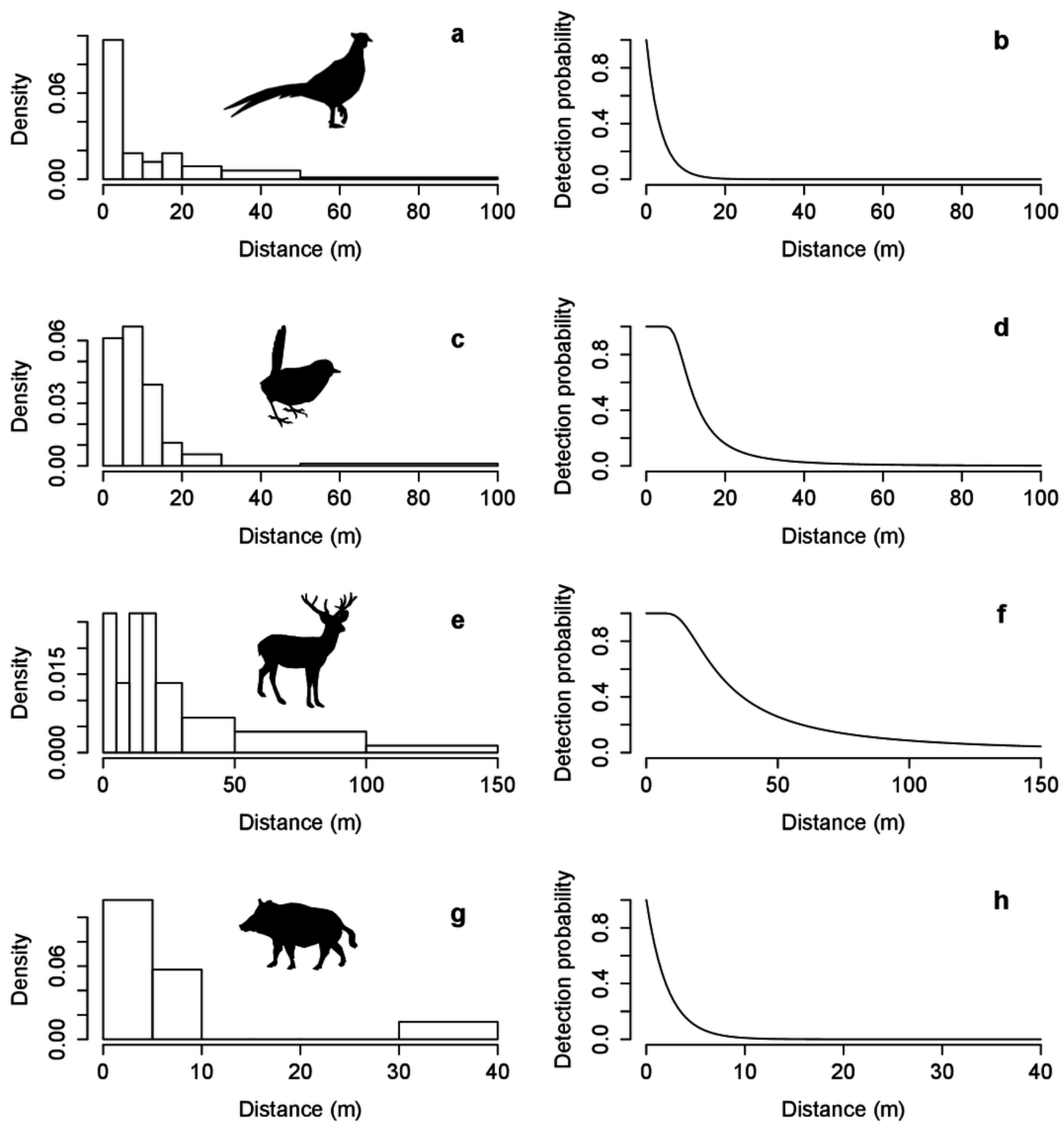